\title{
Reading and Writing Learning Strategies for Low English Proficiency Students at a Private University in China
}

\author{
Yanfang Zhang ${ }^{1}$, Pengfei $\mathrm{Chen}^{2} \&$ Tao $\mathrm{Yu}^{3}$ \\ ${ }^{1}$ CHINA-ASEAN International College, Dhurakij Pundit University/ School of Foreign Studies, Shandong Yingcai \\ University \\ ${ }^{2}$ CHINA-ASEAN International College, Dhurakij Pundit University \\ ${ }^{3}$ Henan Childream Foreign Language School \\ Correspondence: Pengfei Chen, 110/1-4 Prachachuen Road, Laksi, Bangkok 10210, Thailand. E-mail: \\ blissfulalice@gmail.com
}

Received: May 22, 2019

Accepted: June 9, 2019

Online Published: June 11, 2019

doi:10.5430/ijhe.v8n3p214

URL: https://doi.org/10.5430/ijhe.v8n3p214

\begin{abstract}
This study aimed at applying English reading and writing strategies' training to improve the low English proficiency students' competence of English reading and writing. It was a quasi-experiment design. In total, 70 non-English major undergraduates at a private university in China participated in the research, 35 students in the experimental group and the rest 35 students in the control group. The intervention of English reading and writing strategies training was applied to the experimental group over a 24-lesson period in 6 weeks. The control group received an English reading and writing course without the intervention in the same period of the class schedule. Meanwhile, this study applied SILL and PET to the pre-test and the post-test, and used statistical analysis to do data analysis. The result of a detailed one-way ANCOVA showed that the intervention of English reading and writing strategies training in the experimental group had a significant improvement in English reading and writing skills.
\end{abstract}

Keywords: college English, low English proficiency students, reading and writing learning strategies' training

\section{Introduction}

In China, English as a foreign language (EFL) has been conducted in Education more than one century (Liu, Xue, \& $\mathrm{Hu}, 2019)$. However, according to Hewitt and Stephenson (2012), undoubtedly language learning process is a very upsetting experience for many students. Many EFL learners feel anxious and stressful even if they are well prepared for language class (Ayub \& Lodhi, 2016). It is a fact that most Chinese college students spend more than ten years studying English, focusing on reading and writing, however, it is difficult for students to make progress (Zhao, 2008). Chinese students have encountered problems, difficulties, and challenges in English writing, which resulted in the students' limited writing proficiency (Sang, 2017).

EFL students with low English reading proficiency have confronted worse difficulties in the class (Lu \& Liu, 2015). Jandok (2014) mentions how to read an English text and reading strategies were seldom explicitly taught in English class. Meanwhile, Qi (2014) claims that numerous poor EFL English learners at different learning stages are also indisputable in China. In addition, Liu (2005) states that performance of language proficiency is related to learning strategies applied by students. Thus, EFL educators develop strategies for learning and memorizing information to relieve and overcome difficulties they encounter during the process of language studying (Hong-Nam \& Leavell, 2006; Lee, 2010). Using learning strategies aims to make learning easier, faster, more enjoyable, more self-directed, more effective and more transferable (Oxford, 1990). Therefore, a language learning strategy becomes important for students to improve their efficient, improved and autonomous learning (e.g., Macaro, 2006; Griffiths \& Cansiz, 2015). And unsuccessful students' English language can be improved by focusing on metacognitive language learning strategies in their classes (Ghadirzadeh, Hashtroudi, \& OmidShokri, 2013). Language and strategic competencies are the two major components of language ability (Ghafournia1\& Afghari, 2013).

Language learning strategy is the skill, method or other conscious behavior adopted by learners to optimize the learning process and strengthen the memory of language knowledge and information (Ellis, 2013). According to O'Malley and Chamot (1990), reading and writing strategies can be divided into metacognitive, cognitive and social/emotional strategies: metacognitive strategies are used to plan, monitor and evaluate the use of cognitive 
strategies; cognitive strategies are used in the specific activities of language learning; social/affective strategies refer to learners communicating with others, controlling their emotions, and eliminating insecurity and anxiety in order to complete a certain learning task.

Reading strategy is a behavioral process adopted by learners to solve reading difficulties (Johnson, 1998). Since the late 1970s and early 1980s, second language (L2) researchers have gradually realized the importance of reading strategies and conducted some relevant empirical studies, including studying the strategies used by students in the reading process and their relationship with successful and unsuccessful reading (Block, 1986; Jiménez, García,\& Pearson,1996). The research shows that the L2 reading level is different, and the strategies used by learners are different, and the strategies used by high-level readers are more diverse and more reasonable and effective (Block, 1992; Jiménez, García,\& Pearson,1996). Learners, especially those who are not good readers, can improve their reading ability by training some effective strategies for successful readers (Carrell, Pharis, \& Liberto, 1989). Thus, the reading strategies instruction for low proficiency readers is worth surveying with a hypothesis that the reading strategies training for poor readers will be beneficial for improving their reading competence (Madariaga Orbea \& Martínez Villabeitia, 2010).

Academically, writing strategies refer to techniques that language learners or writers use to control while writing and use to improve their piece of writing via three main steps: planning, drafting/writing, and revising (Raimes, 2005). The effective writing strategies can reduce the burden of cognitive resources, so that learners have more resources to conceive and write essays, choose words and sentences, and successfully complete writing tasks (Flower \& Hayes, 1981).

As above, EFL college learners with low proficiency are an issue in China. Accordingly, the study conducted experimental research to apply reading and writing strategies to EFL learners with low proficiency at a private university in China to develop their competency to use English learning strategies effectively toward enhancing language proficiency.

\subsection{Language Learning Strategies}

Learning strategies are defined as "specific actions, behaviors, steps, or techniques, such as seeking out conversation partners, or giving oneself encouragement to tackle a difficult language task used by students to enhance their own learning" (Scarcella \& Oxford, 1992, p.63). O'Malley and Chamot (1990) state that learning strategies as "the special thoughts or behaviors that individuals use to help them comprehend, learn, or retain new information" (p. 1). Yet students do not always realize the importance and the effectiveness of using L2 learning strategies (Nyikos \& Oxford, 1993). Teachers should strengthen learning strategies training and enable learners to utilize more suitable tactics to enhance effective outcome (Oxford, 2003).

According to the information processing theory, O'Malley and Chamot (1990) divide learning strategies into three categories: cognitive, metacognitive, and social/affective strategies. Cognitive strategies are used while learners do specific learning assignments (Lee \& Heinz, 2016). Metacognitive strategies refer to make plans for learning, making reflections on the learning process, monitoring one's production or comprehension, and making an evaluation on learning after an activity is completed (Purpura, 1997). Socio-affective strategies are employed with social mediating activity in interactions with others (Lee \& Heinz, 2016). The study of O'Malley and Chamot (1990) finds that in a foreign language or second language learning, 53\% of the students use cognitive strategies, $30 \%$ use metacognitive strategies, and $17 \%$ use social/affective strategies. They believe that metacognitive strategies are superior to the other two strategies and are high-level behaviors, which have an indirect impact on language acquisition (Qi, 2014). Therefore, in this study, cognitive, metacognitive, and social/affective strategies are applied as the main strategies for English reading and writing strategies training.

\subsection{Reading Strategies}

Reading strategies are the behaviors adopted to solve the difficulties in reading. It includes not only some reading techniques, but also the selective and controlling behaviors the readers adopt to achieve the expected reading purposes (Johnson \& Johnson, 1998). The phrase "English reading strategies" in this study refers to a series of effective methods that help learners solve reading difficulties and thus improve reading efficiency. The study of reading strategies is developed on the basis of language learning strategies. O'Malley \& Chamot (1990) and Oxford (1990) provide a detailed and comprehensive classification of reading strategies in language learning. In terms of cognitive, metacognitive, and social/affective strategies applied to reading, cognitive strategies include induction, analysis, note-taking, reorganization, contextualization, judgment, keywords, and inference. Metacognitive strategies are used to manage and monitor the use of cognitive strategies, including directed attention, selective attention, 
self-management, self-monitoring, and self-evaluation. Social/affective strategies refer to emotional monitoring, cooperation, and emotional motivation in the process of reading (Oxford, 1990; O'Malley \& Chamot, 1990).

\subsection{Writing Strategies}

Writing strategies are "the actions or methods that learners consciously take to make writing more effectively" (Cohen, 1998). Arndt (1987) advocates that writing strategies include eight main categories: planning, global planning, rehearsing, repeating, re-reading, questioning, revising, and editing. Based on Oxford's learning theory (1990) about the basic knowledge of writing, the present study defines writing strategies as the consciousness and behavioral methods related to writing, and the methods and techniques used to improve the efficiency and quality of English writing, to express writing goals accurately, to make the writing consistent in content and form, and to use the information properly.

According to the classifications of Oxford (1990), and O'Malley \& Chamot (1990), writing strategies are corresponding with reading tactics, which also include cognitive strategies, metacognitive strategies, and affective strategies. Cognitive strategies operated directly on incoming information, manipulating it to enhance learning, for example, by rehearsal, organization, and elaboration. Metacognitive strategies are the cognitive management that learners use in order to control the macro process of writing. And social and affective strategies are often treated as a broad grouping involving interaction with other people or being about controlling one's feelings about language learning (O’Malley \& Chamot, 1990).

As above, this study aimed to train Chinese EFL college students to adopt reading and writing learning strategies based on Oxford's and O'Malley \& Chamot's theories to enhance learners' English language proficiency at a private university in China.

\section{Methods}

This study was a quasi-experiment design with non-equivalent control groups. The research treatment of English reading and writing learning strategies training was implemented to evaluate the outcome of English reading and writing competence of the EFL students with low English proficiency. The independent variables were EFL students with low English proficiency. A pre-test and a post-test were applied to evaluate the effectiveness of EFL students with low English proficiency in reading and writing learning.

\subsection{Participants}

In this study, the sample is consisting of non-English major undergraduates at a private university in China, who are disadvantaged English learners in terms of English proficiency at the National College Entrance Examination. In total, 70 students with low proficiency in college English learning in the freshman year at this university are chosen as the sample. In terms of the sequence of the student ID number, the first 35 students were assigned to the experimental group (EG). And the rest 35 were allocated to the control group (CG). There were 56 female and 14 male students totally. The experimental group attended English reading and writing strategies training in the English class. The control group was in the regular college English course.

\subsection{Research Intervention}

The experiment was designed for English reading and writing learning strategies training to non-English major freshman at a private university in China. The training for English reading and writing learning strategies in the experimental group had 6 units, which were implemented over 24 lessons for 6 weeks, one lesson was 60 minutes. The material was New Horizon College English 3 (third edition). The procedure of conduction was to apply cognitive, metacognitive, and affective reading strategies from week 1 to week 3 , and then cognitive, metacognitive, and affective writing strategies from week 4 to week 6 (See Table 1). In contrast, the control class did not take any interventional training. However, in order to parallel variance motivation, expectations, and comfort effects to measure improvement, the study applied an active control class (Chen, Tolmie \& Wang, 2017). The control class also had 24 lessons for 6 weeks with English reading and writing learning in the regular English class. The teaching material was the same as the experimental group, but the reading and writing learning strategies training were not implemented to the control group. 
Table 1. Teaching design of English reading and writing learning strategy training.

\begin{tabular}{lll}
\hline Unit Theme & $\begin{array}{l}\text { Teaching } \\
\text { Materials }\end{array}$ & Course objectives \\
\hline Unit 1 & New & 1. How \\
The way to & $\begin{array}{l}\text { Horizon } \\
\text { College } \\
\text { English } 3\end{array}$ & $\begin{array}{l}\text { to use rearning strategies } \\
\text { success }\end{array}$ \\
& (third & 2.How to \\
& edition); & use writing \\
& Shanghai & learning \\
Unit 2 & foreign & strategies \\
Beat your & language & \\
fear & teaching & \\
& and & \\
& research & \\
& press. &
\end{tabular}

Unit 3

Life stories

Unit4

Let's Go

\section{Unit 5}

When work is

a pleasure
Training topics on learning strategies

Week 1 (4 periods):

To train students in metacognitive reading strategies: planning, monitoring and evaluation, and cognitive reading strategies: word-formation and semantic guessing by means of context.

\section{Week 2 (4 periods):}

To train students in how to analyze the structure of sentences and understand their potential meanings, and how to grasp cognitive reading strategies: analyzing paragraph structure and categorizing the type of text.

\section{Week 3 (4 periods):}

To train students in cognitive reading strategies: skimming, scanning and predicting.

(Weeks 1-3 reading strategies training)

\section{Week 4 (4 periods):}

To train students in

Metacognitive writing strategies: planning, monitoring and evaluation, and writing cognitive strategies: training in taking notes, retrieving and memorizing existing relevant background knowledge and diagrams.

\section{Week 5 (4 periods):}

To train students how to organize the structure of the article and elaborate on their writing.

\section{Week 6 (periods):}

To train students to grasp writing learning strategies: inference, summary, verification and editing.

(Weeks 4-6: writing strategies training)

Unit 6

War and peace

\subsection{Pre-Test and Post-Test}

This study applied the Strategy Inventory for Language Learning (SILL, version 7.0) scale made by Rebecca Oxford in 1990 to investigate whether or not the students applied the reading and writing learning strategies effectively after the training intervention. This is a self-assessment for students. The SILL has been widely utilized and its reliability and validity has also been detected extensively in many ways (Oxford and Burry-Stock, 1995). More than 45 researches about the reliability and validity of SILL scale has been occurred, which include nearly 8,500 learners all over the world (Oxford \& Burry-Stock, 1995). And the research findings indicate that the relationship between SILL learning strategies and English proficiency is significant, which indicates that SILL scale had good construct validity 
(Nisbet, Tindall, \& Arroyo, 2005). Generally, the translated versions of SILL have high reliability. The Cronbach's alpha of the SILL is .94 in Chinese translation (Hsiao \& Oxford, 2002; Yang, 1999), and .93 in Korean and Japanese translation (Park, 1997; Robson \& Midorikawa, 2001). In addition, the Preliminary English Test (PET), which was made by Cambridge Assessment English, is used to examine the students' language proficiency. It is verified as the level of B1 based on the Common European Framework of Reference for Languages (CEFR).

The tools of SILL and PET were applied as the pre-test and the post-test in this study. SILL scores averaging 3.5 - 5.0 are designated as high; 2.5- 3.4 are considered medium strategy utilization; and scores ranging from $1.0-2.4$ are often labeled as low strategy use (Oxford and Burry-Stock 1995). The SILL has 3 dimensions including cognitive, metacognitive, and affective strategies to investigate the use of reading and writing strategies. The PET score is 120 points in total, the reading and writing section is 50\% (60 points in total, 35 points for reading and 25 points for writing) of the total score. This study mainly focused on reading and writing so that the pre-test and the posttest only applied the sections of reading and writing in the PET. One week before the experiment, the SILL and the PET were conducted in the pre-test. The same tools were applied to the post-test after the intervention.

\section{Results}

The 70 students in both the experimental group and the control group took PET and SILL for the pre-test and the posttests. The data was analyzed statistically. The descriptive analysis of the sample was shown in Table 2 . The sample includes 3 male and 32 female students in the experimental group, and 11 male and 24 female in the control group. Both groups' English proficiency was considered as low proficiency learners in terms of the result of NCEE. Also, they have learned English for more than 10 years.

Table 2. Descriptive Analysis of Sample

\begin{tabular}{lllll}
\hline Groups & Items & Item Distinction & $\mathrm{N}$ & $\begin{array}{l}\text { Valid } \\
\text { percentage }\end{array}$ \\
\hline EG & Gender & Male & 3 & $8.6 \%$ \\
& & Female & 32 & $91.4 \%$ \\
& NCEE & $60-70$ & 9 & $25.7 \%$ \\
& & $71-81$ & 26 & $74.3 \%$ \\
& Times for English & Within 10 years & 7 & $20 \%$ \\
& Learning & $10-15$ years & 28 & $80 \%$ \\
& & & & \\
& & Male & 11 & $31.4 \%$ \\
GG & Gender & Female & 24 & $68.6 \%$ \\
& NCEE & $60-70$ & 7 & $20 \%$ \\
& & $71-81$ & 28 & $80 \%$ \\
& Times for English & Within 10 years & 8 & $22.9 \%$ \\
& Learning & $10-15$ years & 27 & $77.1 \%$
\end{tabular}

Notes: NCEE refers to the National College Entrance Examination, which is an important academic examination held annually in the People's Republic of China. The most majority of students participated in NCEE choose English, which refers to a compulsory subject as a foreign language test, and the full mark of English test is 150. The score is less than 80, which is considered as low English proficiency (Zhang, 2016).

\subsection{The Outcome of SILL (Reading and Writing Learning Strategies Test)}

In total, there were 27 items in SILL for the pre- test and the post-test respectively. The design of questionnaire was a five-point Likert scale from strongly agree to strongly disagree descriptions (Norman, 2010). SILL scores averaging 3.5 - 5.0 are designated as high; 2.5-3.4 are considered as medium strategy utilization; and scores ranging from 1.0 2.4 are often labeled as low strategy use (Oxford and Burry-Stock 1995). Tables 3 and 4 shows the descriptive analysis on the reading and writing strategies for the pre-test and the post-test. As tables 3 and 4 , it can be seen that both groups did not show distinctive different means on the use of reading and writing strategies for the pre-test. However, for the posttest, the experimental group showed higher scores on the use of both strategies than the control group. 
Table 3. Descriptive Analysis of the reading strategies for pre and post tests

\begin{tabular}{lllllll}
\hline \multirow{2}{*}{ Variables } & & \multicolumn{3}{c}{ Pre-test } & Post-test \\
\hline CRLS & Groups & $N$ & Mean & $S D$ & Mean & $S D$ \\
\hline \multirow{2}{*}{ MRLS } & CG & 35 & 2.91 & 1.12 & 4.44 & 0.32 \\
& EG & 35 & 2.55 & 0.97 & 2.23 & 1.11 \\
ARLS & CG & 35 & 2.73 & 1.17 & 4.45 & 0.44 \\
& EG & 35 & 2.84 & 1.25 & 4.46 & 0.48 \\
Total & CG & 35 & 2.55 & 0.10 & 2.36 & 1.14 \\
& EG & 35 & 8.48 & 3.44 & 13.35 & 1.10 \\
& CG & 35 & 7.49 & 2.80 & 7.00 & 3.33
\end{tabular}

Notes: CRLS: Cognitive Reading Learning Strategies, MRLS: Meta-cognitive Reading Learning Strategies, ARLS: Affective Reading Learning Strategies, CWLS: Cognitive Writing Learning Strategies, MWLS: Meta-cognitive Writing Learning Strategies, AWLS: Affective Writing Learning Strategies; EG: Experimental Group, CG: Control Group.

Table 4. Descriptive Analysis of the writing strategies for pre and post tests

\begin{tabular}{lllllll}
\hline & & \multicolumn{3}{c}{ Pre-test } & \multicolumn{2}{c}{ Post-test } \\
Variables & Groups & $N$ & Mean & $S D$ & Mean & $S D$ \\
\hline CWLS & EG & 35 & 2.93 & 1.12 & 4.48 & 0.36 \\
& CG & 35 & 2.46 & 1.03 & 2.36 & 1.07 \\
MWLS & EG & 35 & 2.98 & 1.19 & 4.51 & 0.35 \\
& CG & 35 & 2.53 & 1.01 & 2.34 & 1.10 \\
AWLS & EG & 35 & 2.89 & 1.12 & 4.45 & 0.43 \\
& CG & 35 & 2.66 & .96 & 2.33 & 1.06 \\
Overall & EG & 35 & 8.80 & 3.35 & 13.45 & 1.05 \\
& CG & 35 & 7.64 & 2.93 & 7.03 & 3.19 \\
\hline
\end{tabular}

\subsection{The Outcome of PET}

The reading and writing questions in PET are subdivided into eight sections with a total of 42 questions. The first five parts are for reading comprehension, while the last three are for writing. The questions are divided into multiple-choice questions and fill-in-the-blank questions, as well as two short-text writing questions (writing short letters or postcards, or writing a short story). The PET test score is 120 points in total, the reading and writing section is 50\% (60 points in total including 35 points for reading and 25 points for writing) of the total score. Table 5 shows the descriptive analysis of the reading and writing tests in the pre-test and the post-test. In general, the students both in the experimental group and the control group made progress over 24 lessons. The outcome of reading and writing tests presents lower scores on pretest and progressed grades on posttest for both groups. However, the experimental group improved better results than the control group.

Table 5. Descriptive analysis of the PET for pre and post tests

\begin{tabular}{lllllll}
\hline & & \multicolumn{2}{c}{ Pre-test } & \multicolumn{2}{c}{ Post-test } \\
Variables & Groups & $N$ & Mean & $S D$ & Mean & $S D$ \\
\hline Reading & EG & 35 & 22.86 & 3.05 & 28.49 & 3.01 \\
& CG & 35 & 22.14 & 3.17 & 22.91 & 2.69 \\
\multirow{2}{*}{ Writing } & EG & 35 & 11.34 & 2.38 & 18.51 & 2.57 \\
& CG & 35 & 12.31 & 2.01 & 15.69 & 3.03 \\
& & & & & & \\
\hline
\end{tabular}




\subsection{Paired-Sample T-Test for SILL on the Use of Reading and Writing Learning Strategies}

About the use of English reading and writing learning strategies of the EFL students with low English proficiency in a private university, a paired-sample t-test was applied to analyze the English reading and writing strategies of students both in the experimental group and the control group. Table 6 shows that the experimental group had a significant progression $(p<0.01)$ on overall score of English reading and writing learning strategies; on the contrary, the control group had no significant progress $(p>0.05)$ on overall score, indicating that the students in the experimental group could use reading and writing learning strategies effectively after training. In contrast, the control group did not grasp any effective tactics on English reading and writing.

Table 6. Summary of paired-sample $t$-test for the use of reading and writing learning strategies

\begin{tabular}{|c|c|c|c|c|c|c|}
\hline Variables & $\begin{array}{l}\text { Groups } \\
(\mathrm{N}=35)\end{array}$ & $\begin{array}{l}\text { Mean } \\
\text { of pr } \\
\text { tests }\end{array}$ & $\begin{array}{l}\text { difference } \\
\text { e and post } S D\end{array}$ & $t$ & $d f$ & $p$ \\
\hline \multirow[t]{2}{*}{ CRLS } & EG & 1.53 & 1.15 & 7.87 & 34 & .00 \\
\hline & CG & -.26 & 1.53 & -.99 & 34 & .33 \\
\hline \multirow{2}{*}{ MRLS } & EG & 1.72 & 1.26 & 8.10 & 34 & .00 \\
\hline & $\mathrm{CG}$ & -.04 & 1.47 & -.16 & 34 & .87 \\
\hline \multirow{3}{*}{ ARLS } & EG & 1.62 & 1.29 & 7.46 & 34 & .00 \\
\hline & $\mathrm{CG}$ & -.19 & 1.48 & -.74 & 34 & 46 \\
\hline & EG & 1.55 & 1.15 & 7.99 & 34 & .00 \\
\hline \multirow[t]{2}{*}{ CWLS } & CG & -.09 & 1.54 & -.38 & 34 & .71 \\
\hline & EG & 1.53 & 1.20 & 7.53 & 34 & .00 \\
\hline \multirow[t]{2}{*}{ MWLS } & $\mathrm{CG}$ & -.19 & 1.53 & -.72 & 34 & 48 \\
\hline & EG & 1.56 & 1.18 & 7.81 & 34 & .00 \\
\hline AWLS & $\mathrm{CG}$ & -.33 & 1.43 & -1.35 & 34 & .19 \\
\hline \multirow{2}{*}{$\begin{array}{l}\text { Overall score } \\
\text { reading }\end{array}$} & EG & 4.87 & 3.55 & 8.13 & 34 & .00 \\
\hline & CG & -.48 & 4.37 & -.65 & 34 & .00 \\
\hline \multirow{2}{*}{$\begin{array}{l}\text { Overall } \\
\text { writing }\end{array}$} & EG & 4.65 & 3.45 & 7.98 & 34 & .52 \\
\hline & $\mathrm{CG}$ & -.61 & 4.43 & -.81 & 34 & .42 \\
\hline
\end{tabular}

$(p<0.01)$

\subsection{Paired-Sample T-Test for PET}

Regarding English reading and writing performance of the EFL students with low English proficiency in a private university, a paired-sample t-test was applied to examine the English proficiency in the experimental group and the control group before and after the intervention. Table 7 shows that both groups had a significant progression $(p<$ 0.05 ) on overall score of English reading and writing, indicating that the students' result of pre-test and post-test was a significant difference. The result of the post-test was higher than the pretest, and the experimental group got the better result than the control group.

Table 7. Summary of paired-sample $t$-test for PET

\begin{tabular}{llllllll}
\hline \multirow{2}{*}{ Test } & Groups & $\begin{array}{l}\text { Mean difference } \\
\text { of pre and post }\end{array}$ & $S D$ & $t$ & $d f$ & $p$ \\
\hline Reading & EG & 5.63 & 3.14 & 10.59 & 34 & .00 \\
& CG & .77 & 1.86 & 2.44 & 34 & .02 \\
\multirow{3}{*}{ Writing } & EG & 7.17 & 2.16 & 19.62 & 34 & .00 \\
& CG & 3.37 & 2.34 & 8.52 & 34 & .00 \\
\hline
\end{tabular}

$(p<0.05)$ 


\subsection{Analysis of Covariance (ANCOVA) about SILL}

A one-way ANCOVA was conducted to determine a statistically significant difference between the experimental group and the control group on the post-test controlling for the pre-test. Table 8 shows the result of analysis of ANCOVA about SILL.

The homogeneity of the regression coefficients in the group in initial test, it showed no significant difference between the experimental group and the control group. The result of the pre-test presented CRLS $(F=0.27, p$ $=0.60>0.05)$, MRLS $(F=.00, p=0.93>0.05)$, ARLS $(F=.01, p=0.90>0.05)$, CWLS $(F=.27, p=0.27>0.05)$, MWLS $(F=.20, p=0.66>0.05)$, and AWLS $(F=.01, \mathrm{p}=0.93>0.05)$, indicating that there was no significant effect of the two groups on the post-test after controlling the pre-test. The result of analysis of covariates also showed that there was a significant effect of the two groups on the use of reading and writing strategies post-test, CRLS $[F(2,67)=117.94, p<$ $0.01]$, MRLS $[F(2,67)=109.50, p<0.01]$, ARLS[F(2,67)=106.48, $p<0.01], \operatorname{CWLS}[F(2,67)=122.72, p<0.01]$, $\operatorname{MWLS}[F(2,67)=119.30, p<0.01]$, and AWLS $[F(2,67)=117.87, p<0.01]$, indicating that the score of reading and learning strategies test of experimental group on the post-test was significant higher than the control group.

Table 8. Summary of One-way ANCOVA about SILL

\begin{tabular}{lllllll}
\hline Source & Source & $S S$ & $d f$ & $M S$ & $F$ & $p$ \\
\hline CRLS & Covariate & .08 & 1 & .080 & .119 & .73 \\
& Group & 158.60 & 2 & 79.30 & 117.94 & .00 \\
& Error & 45.05 & 67 & .67 & & \\
MRLS & Covariate & .001 & 1 & .001 & .001 & .98 \\
& Group & 166.21 & 2 & 83.10 & 109.50 & .00 \\
& Error & 50.85 & 67 & .76 & & \\
ARLS & Covariate & .20 & 1 & .20 & .26 & .61 \\
& Group & 165.37 & 2 & 82.69 & 106.48 & .00 \\
& Error & 52.03 & 67 & .78 & & .78 \\
& Covariate & .05 & 1 & .05 & .08 & .00 \\
& Group & 158.89 & 2 & 79.45 & 122.72 & .98 \\
& Error & 43.37 & 67 & .65 & & .00 \\
MWLS & Covariate & .00 & 1 & .00 & .00 & .90 \\
& Group & 161.15 & 2 & 80.58 & 119.30 & .00 \\
& Error & 45.25 & 67 & .675 & & .01 \\
\hline
\end{tabular}

$$
(p<0 . \overline{01})
$$

\subsection{Analysis of Covariance (ANCOVA) about PET}

Table 9 shows the result of summary of one-way ANCOVA about PET. The homogeneity of the regression coefficients in the group in initial test, it showed no significant difference between the experimental group and the control group. The result of the pre-test displayed reading $(\mathrm{F}=1.77, \mathrm{p}=0.19>0.05)$, and writing $(\mathrm{F}=1.32, \mathrm{p}=0.62>0.05)$, indicating that there was no significant effect of the two groups on the post-test after controlling the pre-test. The result of the final analysis of covariates showed that there was a significant effect of the two groups on the PET for reading $[\mathrm{F}(2,67)=72.22, p<0.05]$ and writing $[\mathrm{F}(2,67)=45.29, p<0.05]$ on the post-test, and indicating that the performance of experimental group on the post-test was significant better than the control group. 
Table 9. Summary of One-way ANCOVA about PET tests

\begin{tabular}{lllllll}
\hline Tests & Source & $S S$ & $d f$ & $M S$ & $F$ & $p$ \\
\hline Reading Test & Covariate & 219.10 & 1 & 219.10 & 43.64 & .00 \\
Writing Test & Group & 603.61 & 2 & 301.81 & 72.22 & .00 \\
& Error & 336.39 & 67 & 5.02 & & \\
& Covariate & 205.66 & 1 & 205.66 & 41.68 & .00 \\
& Group & 446.95 & 2 & 223.48 & 45.29 & .00 \\
& Error & 330.63 & 67 & 4.94 & & \\
\hline
\end{tabular}

$(p<0.01)$

Consequently, a one-way ANCOVA was implemented to analyze a statistically significant difference on the use of reading and writing learning strategies and their effects to the result of English proficiency. And there was a significant difference of the two groups both on the reading and writing learning strategies tests, which led to a significant difference on the effect of English reading and writing proficiency of the two groups. And it indicated that the score of the experimental group was higher than the control group. Therefore, after the intervention, the experimental group had better improvement on reading and writing ability than the control group.

\section{Discussion}

This study aimed to examine how effective reading and writing learning strategies in improving the performance of Chinese EFL students with low proficiency in private universities in China. Both reading and writing strategies can be divided into three dimensions including cognitive, meta-cognitive, and affective strategies. The result provides the support. As predicted, the level of Chinese EFL college students' use reading and writing learning strategies influence their language proficiency. Previous studies showed that the learning strategy and learning performance having a closed inter-relation (Rahimy \& Shams, 2012). The strategy instruction could enhance students' language learning outcomes (Oxford, 2001), and "any intervention which focuses on the strategies to be regularly adopted and used by language learners to develop their proficiency, to improve particular task performance" (Hassan et. al., 2005, p. 1), or both strategy training aims to "empower students", so that they can take the control of their own learning process (Cohen, 1998, p. 70). Our findings develop based on this to illustrate that the effective strategies training can improve students' learning performance and learning ability.

According to the finding, the Chinese EFL college students were trained to use reading and writing learning strategies over 24 lessons. Their English proficiency was enhanced afterward, although they had been scored as the low proficiency learners.

\section{Conclusion}

The study was aimed to apply the training of reading and writing learning strategies to Chinese EFL college students with disadvantage language competence toward enhancing their English proficiency. This was a quasi-experiment design with two types of classes, the 35 students in the experimental group with the reading and writing learning strategy coaching and the other 35 students without intervention in the control group. In total, the effective sample was 70 Chinese EFL freshmen with low English proficiency in a private university. The intervention was conducted over 24 lessons in 6 weeks.

It can be concluded that after the reading and writing learning strategy training for 24 lessons, both the experimental and control groups were improved on the pre-test and the post-test of PET. However, the English proficiency of the experimental group was progressed significantly than the control group since the students in the experimental group was improved significantly on the pre-test and the post-test of the use of English reading and writing learning strategies. In contrast, the control group had no progression.

In summary, the English reading and writing learning strategy training was able to improve the reading and writing abilities for EFL students with low English proficiency in a private university. Once Chinese EFL students with low language proficiency can conduct reading and learning strategies effectively, their English competency would enable a large increase.

\section{Implication}

The study is to contribute the field of EFL education's administrators and instructors to understand the way of applying learning strategy training for EFL students with low English proficiency students in Chinese private 
universities. However, an imbalance of males, the design of teaching materials, limited experimental time and classroom environment were somehow limited to assist EFL students learning strategies fully. The future study may develop more creative, innovative and unrestrained surroundings to conduct the English learning strategies training such as online distance courses assisting EFL students not only with low English proficiency students but high English proficiency learners to compare differences.

\section{Acknowledgements}

The research is grant from Shandong Yingcai University. Firstly, the author thanks her principal supervisor for help revise the paper and patient instruction; secondly, the author thanks her friend for help data collection; lastly, the authors thank some teachers in Shandong Yingcai University for helping to collect data used in this study.

\section{References}

Arndt, V. (1987). Six writers in search of a text: A protocol based study of L1 and L2 writing. ELT Journal, 41, (4), 257-267. https://doi.org/10.1093/elt/41.4.257

Ayub, S., \& Lodhi M. A. (2016). Identification of the teacher's debilitating attitude involved in acquiring oral competency of ESL students at graduate level. Journal of English Literature and Language Review, 2(2), 43-48.

Block, E. L. (1986). The comprehension strategies of second language readers. TESOL Quarterly, 20 (3), 463-494. https://doi.org/10.2307/3586295

Block, E. L. (1992). See how they Read: Comprehension Monitoring of L1 and L2 Readers. TESOL Quarterly, 26(2), 319-43. https://doi.org/10.2307/3587008

Cambridge Assessment English (2019). B1 Preliminary. Retrieved from https://www.cambridgeenglish.org/exams-and-tests/preliminary/

Carrell, P. L., Pharis, B. G., \& Liberto, J. C. (1989). Metacognitive strategy training for ESL reading. TESOL Quarterly, 23 (4), 647-678. https://doi.org/10.2307/3587536

Chen, P., Tolmie, A. K., \& Wang, H. (2017). Growing critical thinking of school children in Taiwan using. International Journal of Educational Research, 84, 43-54. https://doi.org/10.1016/j.ijer.2017.02.002

Cohen, A. D. (1998). Strategies in learning and using a second language. New York: Longman.

Ellis, N. C. (2013). Second language acquisition. In G. Trousdale \& T. Hoffmann (Eds.), Oxford handbook of construction grammar (pp. 365-378), Oxford: Oxford University Press.

Flower, L., \& Hayes, J.R. (1981). A cognitive process theory of writing. College Composition and Communication, 32, 365-387. http://dx.doi.org/10.2307/356600

Ghadirzadeh, R. Hashtroudi, P. F., \& Shokri, O. (2013). Study of the Effective Factors on the University Students' Underachievement in English Language Learning. English Language Teaching, 6(11), 122-129.Griffiths, C. (2008). Strategies and good language learners. In C. Griffiths (Ed.), Lessons from good language learners (pp.83-98). Cambridge, UK: Cambridge University Press. http://dx.doi.org/10.5539/elt.v6n11p122

Ghafournia, N., \& Afghari, A. (2013). Relationship between reading proficiency, strategic competence, and reading comprehension test performance: A study of Iranian EFL learners. International Education Studies, 6(8), 21. http://dx.doi.org/10.5539/ies.v6n8p21

Ghafournia, N., \& Afghari, A. (2013). The interaction between cognitive test-taking strategies, reading ability, and reading comprehension test performance of Iranian EFL. English Language Teaching, 6 (8), 139-150. http://dx.doi.org/10.5539/elt.v6n8p139

Griffiths, C. , \& Cansiz, G. (2015). Language learning strategies: An holistic view. Studies in Second Language Learning and Teaching, 5(3), 473-493.

Hassan,X., E. Macaro, D. Mason et al.(2005). Strategy Training in Language Learning-A systematic Review of Available Research. In Research Evidence in Education Library. London: EPPI-Center, Social Science Research Unit, Institute of Education, University of London.

Hewitt, E., \& Stephenson, J. (2012). Foreign language anxiety and oral exam performance: A replication of phillips' MLJ study. The Modern Language Journal, 11(3), 70-89. https://doi.org/10.1111/j.1540-4781.2011.01174.x

Hong-Nam, K., \& Leavell, A. (2006). Language learning strategy use of ESL students in an intensive English 
learning context. System, 34, 399-415. https://doi.org/10.1016/j.system.2006.02.002

Hsiao, T.-Y., \& Oxford, R. L. (2002). Comparing theories of language learning strategies: A confirmatory factor analysis. Modern Language Journal, 86 (3), 368-383. https://doi.org/10.1111/1540-4781.00155

Jandok, L. (2014). A componential analysis of reading comprehension in Chinese EFL learners (Doctoral thesis). der Technischen Universität Berlin, Berlin. http://dx.doi.org/10.14279/depositonce-4225

Jiménez, R. T., García, G. E., \& Pearson, P. D. (1996). The reading strategies of students who are successful English readers: opportunities and obstacles. Reading Research Quarterly, 31(1), 90-112. http://dx.doi.org/10.1598/RRQ.31.1.5

Johnson, K., \& Johnson, H. (1998). Encyclopedic dictionary of applied linguistics: a handbook for language teaching. New York: Black-well Publishers Ltd.

Landau, S., \& Everitt, B. S. (2004). A handbook of statistical analyses using SPSS. Boca Raton, FL: Chapman \& Hall. https://doi.org/10.1201/9780203009765

Lee, C. (2010). An overview of language learning strategies. ARECLS, 7, 132-152.

Lee. J., \& Heinz M. (2016). English language learning strategies reported by advanced language learners. Journal of International Education Research, 12(2), 67-76. http://dx.doi.org/10.24127/pj.v7i2.1581

Liu. D. P., Xue S. J., \& Hu, R. (2019). A preliminary study on challenges and solutions for college EFL education in ethnic minority regions of China. English Language Teaching, 12(3), 15-25. https://doi.org/10.5539/elt.v12n3p15

Liu. M. (2005). A study of Chinese university EFL learners' foreign language listening anxiety, listening strategy use and academic listening performance. Indonesian Journal of English Language Teaching, 10 (1), 30-47.

Lu. Z. S., \& Liu. M.H. (2015). An investigation of Chinese university EFL learner's foreign language reading anxiety, reading strategy use and reading comprehension performance. Studies in Second Language Learning and Teaching, 5(1), 65-85. https://doi.org/10.14746/ssllt.2015.5.1.4

Macaro, E. (2006). Strategies for language learning and for language use: Revising the theoretical framework. The Modern Language Journal, 90(3), 320-337. http://doi.org/10.1111/j.1540-4781.2006.00425.x.

Madariaga Orbea, J. M., \& Martínez Villabeitia, E. (2010). The teaching of reading comprehension and meta comprehension strategies. A program implemented by teaching staff. Anales de Psicologia, 26(1), 112-122. Retrieved from https://revistas.um.es/analesps/article/view/92111

Norman, G. (2010). Likert scales, levels of measurement and the "laws" of statistics. Advances in Health Sciences Education, 15(5), 625-32. https://doi.org/10.1007/s10459-010-9222-y

Nyikos, M., \& Oxford, R. (1993). A factor analytic study of language-learning strategy use: Interpretations from information-processing theory and social psychology. The Modern Language Journal, 77(1), 11-22. http://dx.doi.org/10.2307/329553

Nisbet, D.L., Tindall, E.R., \& Arroyo, A.A. (2005). Language learning strategies and English proficiency of Chinese university students. Foreign Language Annals in Proquest Journal, 38(1), 100-108. https://doi.org/10.1111/j.1944-9720.2005.tb02457.x

O'Malley, J. M. \& Chamot, A. U. (1990). Learning strategies in second language acquisition. Cambridge: Cambridge University Press. https://doi.org/10.17265/1539-8080/2017.08.001

Oxford, R. (2003). Language learning styles and strategies: An overview. Proceedings of GALA (Generative Approaches to Language Acquisition) Conference, 1-25. Retrieved from http://web.ntpu.edu.tw/ language/workshop/read2.pdf.

Oxford, R. L. (2001). Language learning styles and strategies. In M. Celece-Murcia (Ed.), Teaching English as a second or foreign language (pp. 359-366). Boston: Heinle \& Heinle. Thompson International.

Oxford, R. L., \& Burry-Stock, J. A. (1995). Assessing the use of language learning strategies worldwide with the ESL/EFL version of the Strategy Inventory for Language Learning (SILL). System, 23(1), 1-23. https://doi.org/10.1016/0346-251X(94)00047-A

Oxford., R. L. (1990). Language learning strategies: what every teacher should know. Boston, Mass.: Heinle \& Heinle. 
Park, G.-P. (1997). Language learning strategies and English proficiency in Korean university students. Foreign Language Annals, 30 (2), 211-221. https://doi.org/10.1111/j.1944-9720.1997.tb02343.x

Purpura, J. E. (1997). An analysis of the relationships between test takers' cognitive and metacognitive strategy use and second language test performance. Language Learning, 47(2), 289-294. https://doi.org/10.1111/0023-8333.91997009

Qi, C. (2014). Empirical study on learning strategies instruction to college English poor learners (Doctoral thesis). Dongbei Normal University, Ji Lin.

Qin, X. Q. (2003). Quantitative data analysis in foreign language teaching research. Wuhan: Huazhong University of Science and Technology Press.

Rahimy, R., \& Shams, K. (2012). An Investigation of the Effectiveness of Vocabulary Learning Strategies on Iranian EFL Learners' Vocabulary Test Score. International Education Studies, 5(5), 141-152. http://dx.doi.org/10.5539/ies.v5n5p141

Raimes, A. (2005). Keys for writers (4th ed.). Boston: Houghton Mifflin.

Robson, G., \& Midorikawa, H. (2001). How reliable and valid is the Japanese version of the Strategy Inventory for Language Learning (SILL)? JALT Journal, 23, 202-226

Sang. Y. (2017). Investigate the "issues" in Chinese students' English writing and their "reasons": revisiting the recent evidence in Chinese academia. International Journal of Higher Education, 6(3), 1-11. https://doi.org/10.5430/ijhe.v6n3p1

Scarcella, R. \& Oxford, R. (1992). The tapestry of language learning: The individual in the communicative classroom. Boston: Heinle \& Heinle. https://doi.org/10.1017/S0272263100012663

Yang, N. D. (1999). The relationship between EFL learners' beliefs and learning strategy use. System, 27, 515-535. http://dx.doi.org/10.1016/S0346-251X(99)00048-2

Zhang. Y. (2016). National university entrance examination for China: Perspectives on education quality and equity. Singapore, Springer. https://doi.org/10.1007/978-981-10-0510-7

Zhao. H. Q. (2008). Using the internet to improve EFL through reading and writing for communicative purpose. Polyglossia, 14, 17-24. 